\title{
Correction to: Genome Analysis and Genomic Comparison of the Novel Species Arthrobacter ipis Reveal Its Potential Protective Role in Its Bark Beetle Host
}

\author{
L. I. González-Dominici ${ }^{1,2}$ (D) $\cdot$ Z. Saati-Santamaría ${ }^{1,2}$ (D) P. García-Fraile ${ }^{1,2,3,4}$ (D)
}

Published online: 15 July 2021

(c) Springer Science+Business Media, LLC, part of Springer Nature 2021

A Correction to this paper has been published: https://doi.org/10.1007/s00248-021-01811-X

\section{Correction to: Microbial Ecology}

https://doi.org/10.1007/s00248-020-01593-8

This addendum is to clarify that the epithet for the species and the protologue of the manuscript have been corrected (previous epithet "ipsi"; current epithet "ipis").

Therefore, the title should be stated as follows: "Genome Analysis and Genomic Comparison of the Novel Species Arthrobacter ipis Reveal Its Potential Protective Role in Its Bark Beetle Host"

And the protologue as follows:

Description of Arthrobacter ipis sp. nov.

Arthrobacter ipis (i'pis. N.L. gen. n. ipis of the bark beetle genus Ips).

Cells form cream, smooth and circular with entire margins colonies when grown for 3 days at $28^{\circ} \mathrm{C}$ on TSA medium. Cells are able to grow at $12-37^{\circ} \mathrm{C}$ with optimum at $28^{\circ} \mathrm{C}$, at $\mathrm{pH} 6.5-8.5$ with optimum at $6.5-7.5$ and in the presence of $0-4 \%$ but not at $5 \%(\mathrm{w} / \mathrm{v}) \mathrm{NaCl}$, with optimum at $0-1 \%(\mathrm{w} / \mathrm{v}) \mathrm{NaCl}$. Cells are short Gram-negative rods with $0.4 \mu \mathrm{m}$ length and $0.1 \mu \mathrm{m}$ width. Catalase positive and oxidase negative. In the API20E system, glucose fermentation/ oxidation test was negative. Positive for aesculin hydrolysis, production of urease, gelatinase and $\beta$-galactosidase and for assimilation of D-mannose, D-mannitol, $\mathrm{N}$-acetyl glucosamine and D-maltose; but negative for reduction of nitrates, glucose fermentation, production of indole and arginine dihydrolase and assimilation of D-glucose, L-arabinose, potassium gluconate, caprate, adipate, malate, trisodium citrate and phenylacetate. Enzyme activities were observed to be positive for alkaline phosphatase, esterase, esterase lipase, acid phosphatase, naphthol-ASBI-phosphohydrolase, $\alpha$-galactosidase, $\beta$-galactosidase, $\alpha$-glucosidase, $\beta$-glucosidase, $\mathrm{N}$-acetyl- $\beta$-glucosaminidase and $\alpha$-mannosidase, but negative for lipase, leucine arylamidase, valine arylamidase, cystine arylamidase, trypsin, $\alpha$-chymotrypsin and a-fucosidase.

The type strain $\mathrm{IA} 7^{\mathrm{T}}\left(=\right.$ CECT $\left.30100^{\mathrm{T}}=\mathrm{LMG} 31782^{\mathrm{T}}\right)$ was isolated from a bark beetle from the species Ips acuminatus in the Czech Republic. The $\mathrm{G}+\mathrm{C}$ base composition was $66.0 \mathrm{~mol} \%$.

The original article can be found online at https://doi.org/10.1007/ s00248-020-01593-8.

P. García-Fraile

paulagarciafraile@usal.es

1 Microbiology and Genetics Department, University of Salamanca, Salamanca, Spain

2 Spanish-Portuguese Institute for Agricultural Research (CIALE), Villamayor, Salamanca, Spain

3 Institute of Microbiology of the Czech Academy of Sciences, Prague, Czech Republic

4 Associated R\&D Unit, USAL-CSIC (IRNASA), Salamanca, Spain 